\title{
Changes in Fungal Population and Aflatoxin Levels and Assessment of Major Aflatoxin Types in Stored Peanuts (Arachis hypogaea Linnaeus)
}

\author{
John M. Wagacha ${ }^{1,2}$, Charity K. Mutegi ${ }^{3,4}$, Maria E. Christie ${ }^{5}$, Lucy W. Karanja ${ }^{6}$ \& Job Kimani ${ }^{1}$ \\ ${ }^{1}$ International Crops Research Institute for the Semi Arid Tropics (ICRISAT), Nairobi, Kenya \\ ${ }^{2}$ School of Biological Sciences, University of Nairobi, Nairobi, Kenya \\ ${ }^{3}$ International Institute of Tropical Agriculture (IITA), Nairobi, Kenya \\ ${ }^{4}$ Kenya Agricultural Research Institute (KARI), Nairobi, Kenya \\ ${ }^{5}$ Virginia Tech, Blacksburg, USA \\ ${ }^{6}$ Centre for Agricultural Bioscience International (CABI), Nairobi, Kenya \\ Correspondence: John M. Wagacha, School of Biological Sciences, University of Nairobi, P. O. Box \\ 30197-00100 Nairobi, Kenya. Tel: 254-715-693-662. E-mail: maina.wagacha@uonbi.ac.ke
}

Received: July 8, 2013 Accepted: July 30, 2013 Online Published: August 1, 2013

doi:10.5539/jfr.v2n5p10 URL: http://dx.doi.org/10.5539/jfr.v2n5p10

\begin{abstract}
Peanut kernels of Homabay Local, Valencia Red, ICGV-SM 12991 and ICGV-SM 99568 cultivars were stored for six months in jute, polypropylene and polyethylene bags to assess the effect of storage bags, temperature and R.H. on fungal population and aflatoxin contamination. Moisture content (M.C.), fungal population and aflatoxin levels were determined before storage and after every 30 days during storage. Isolates of Aspergillus flavus and A. parasiticus were assayed for production of aflatoxin B1, B2, G1 and G2. The correlation between MC, population of $A$. flavus and A. parasiticus and aflatoxin levels in peanuts was also determined. Six fungal pathogens were commonly isolated from the peanut samples and occurred as follows in decreasing order: Penicillium spp. (106.6 CFU/g), A. flavus L-strain (4.8 CFU/g), A. flavus S-strain (2.9 CFU/g), A. niger (2.6 $\mathrm{CFU} / \mathrm{g})$, A parasiticus $(1.7 \mathrm{CFU} / \mathrm{g})$ and $A$. tamarii $(0.2 \mathrm{CFU} / \mathrm{g})$. The overall population of $A$. flavus L-strain was $66 \%$ higher than that of $A$. flavus S-strain. Ninety one percent of $A$. flavus and $A$. parasiticus isolates produced at least one of the four aflatoxin types assayed, with $36 \%$ producing aflatoxin B1. Total aflatoxin levels ranged from $0-47.8 \mu \mathrm{g} / \mathrm{kg}$ with samples stored in polyethylene and jute bags being the most and least contaminated, respectively. Eighty nine percent and $97 \%$ of the peanut samples met the EU $(\leq 4 \mu \mathrm{g} / \mathrm{kg})$ and Kenyan $(\leq 10$ $\mu \mathrm{g} / \mathrm{kg}$ ) regulatory standards for total aflatoxin, respectively. Peanuts should be adequately dried to safe moisture level and immediately packaged in a container - preferably jute bags - which will not promote critical increases in fungal population and aflatoxin contamination.
\end{abstract}

Keywords: aflatoxin, Aspergillus spp., bag types, peanuts

\section{Introduction}

Crops in tropical production areas throughout the world often become contaminated with aflatoxins, which are toxic fungal metabolites (Shephard, 2008). It is estimated that more than five billion people in developing countries are at risk of chronic exposure to aflatoxins through contaminated foods (Strosnider et al., 2006). Fungal growth and aflatoxin contamination of peanuts and other foodstuffs remains a challenge in developing countries where agricultural and food processing systems are not properly designed to handle food safety risks. The challenge is exacerbated by suboptimal postharvest conditions including handling, storage and processing (Wu \& Khlangwiset, 2010).

Nyanza and Western provinces are the leading production regions of peanuts in Kenya with lower contribution from Eastern and Rift Valley provinces (United States Agency for International Development [USAID], 2010). Of the 25,098 hectares planted with peanuts in 2008, Nyanza accounted for $75.6 \%$, Western for $16.3 \%$, Eastern for $4.1 \%$ and Rift Valley for $4 \%$ of the total area. Nyanza and Western provinces account for $89 \%$ of peanuts output while $11 \%$ is produced in the rest of the country. 
Peanuts and maize are the most susceptible crops to aflatoxin contamination (Wu \& Khlangwiset, 2010). The two crops and their products are widely consumed in Kenya. Production of peanuts in Kenya in 2010 was 19,000 tons (FAOSTAT, 2012), with an estimated per capita consumption of $0.5 \mathrm{~kg} / \mathrm{ca}$ (USAID, 2010). On the other hand, production of maize in the country is estimated at 3.14 million MT with a per capita consumption of $98 \mathrm{~kg}$ contributing about $35 \%$ of the daily dietary energy consumption (United States Department of Agriculture [USDA], 2013). Based on these statistics, high consumption of peanut and maize products in the country increases the risk of aflatoxin exposure to consumers. Aflatoxin contamination can occur at pre- and post-harvest stages (Waliyar et al., 2005). During storage, peanuts are prone to various types of deterioration some of which are attributed to growth of storage fungi which cause decrease of germination ability, loss in kernel weight, discoloration of kernels, heating and mustiness, chemical and nutritional changes, and mycotoxin contamination (Malaker, Mian, Bhuiyah, Akanda, \& Reza, 2008).

Aflatoxin is a group of naturally occurring carcinogenic compounds which are mainly produced by Aspergillus flavus (Link), A. parasiticus (Speare) and A. nomius (Kurtzman et al.) (Strosnider et al., 2006). Aflatoxin B1 (AFB1) - the most toxic of the aflatoxins - has been classified by the International Agency for Research on Cancer (IARC) as a group 1 human carcinogen (IARC, 1993). Consumption of aflatoxin contaminated foods affects human health causing aflatoxicosis, cancer, stunted growth in children and/or immune suppression (Shephard, 2008; Wu, 2010) among others. The worst aflatoxicosis outbreak recorded in the world occurred in Kenya in 2004 where 317 cases of aflatoxin poisoning and 125 deaths were reported (Centers for Disease Control and Prevention [CDC], 2004). Other documented fatal aflatoxicosis outbreaks reported in Kenya are: 20 cases in 1981 (Ngindu et al., 1982); 80 cases and 30 deaths in 2005; and 9 deaths in 2006 (Wagacha \& Muthomi, 2008). The health concerns associated with aflatoxin (and other mycotoxins) have led many countries to set standards on acceptable limits of total aflatoxins as well as different aflatoxin types. The upper limit set by European Union for total aflatoxin in peanuts is $4 \mu \mathrm{g} / \mathrm{kg}$ and $2 \mu \mathrm{g} / \mathrm{kg}$ for AFB1 (Commission of the European Communities, 2006), while the corresponding limits by the Kenya Bureau of Standards (KEBS) are 10 and 5 $\mu \mathrm{g} / \mathrm{kg}$, respectively (KEBS, 2007).

Suboptimal postharvest conditions including handling, storage and processing have been suspect in playing a major role in aflatoxin accumulation in food crops within developing countries (Wu \& Khlangwiset, 2010). Most households and traders in Kenya prefer polypropylene and polyethylene bags for packaging and storing peanuts with less than $1 \%$ of the traders storing their products in the recommended jute bags (Mutegi et al., 2013). The packaging/storage material used influences microbial and aflatoxin contamination of stored peanuts (Mutegi et al., 2013) and maize (Hell, Cardwell, Setamou, \& Poehling, 2000).

The aflatoxin producing moulds grow on peanut kernels at high moisture level $\geq 7 \%$ in the presence of temperatures ranging from $21{ }^{\circ} \mathrm{C}$ to $37^{\circ} \mathrm{C}$. Fungal growth in storage facilities is also favored by high relative humidity (R.H.) above 83 - 85\% (Christensen, Mirocha, \& Meronuck, 1977). However, peanuts are stable at $70 \%$ R.H., between 7 - 9\% moisture content (M.C.), at which conditions fungal growth is arrested (Indian Council of Agricultural Research [ICAR], 1987). When peanuts absorb moisture from the environment or when the environmental R.H. exceeds the equilibrium R.H. of the kernels, fungal growth occurs (Hayma, 2003).

Peanuts in Kenya are frequently infected by A. flavus and A. parasiticus (Mutegi, Ngugi, Hendriks, \& Jones, 2012; Wagacha, Mutegi, Karanja, Kimani, \& Christie, 2013) and this infection can occur at all stages in the peanut value chain (Waliyar et al., 2005). Determination of the level of fungal infection of a foodstuff as well as establishing the occurrence of common species is important as the fungal population and diversity could give an indication of the food quality and the presence and types of mycotoxins (Suanthie, Cousin, \& Woloshuk, 2009). Aflatoxin producing fungi occur in three sections of the genus Aspergillus, but section Flavi contains the greatest number of potential aflatoxin producers (Pildain et al., 2008). Based on morphological, genetic and physiological criteria, A. flavus, the main aflatoxin producing species, can be divided into two morphotypes, the $\mathrm{S}$ and $\mathrm{L}$ strains (Cotty, 1994). The S-strain produces high levels of B-aflatoxins with some strains producing both B- and G-aflatoxins (Barros, Torres, Rodriguez, \& Chulze, 2006; Cardwell \& Cotty, 2002), while the L-strain produces less B-aflatoxins (Barros et al., 2006; Probst, Bandyopadhyay, Price, \& Cotty, 2011). Aspergillus parasiticus and A. nomius produce both B- and G-aflatoxins (Cardwell \& Cotty, 2002).

The objectives of this study were to i) assess the effect of storage conditions on fungal population and aflatoxin contamination of peanuts; ii) assess the effect of storage/packaging bags - commonly used in households and markets in Kenya - on fungal population and aflatoxin contamination of peanuts; iii) determine the aflatoxin types produced by isolates of A. flavus and A. parasiticus from peanut kernels. 


\section{Materials and Methods}

\subsection{Storage Conditions and Their Rationale}

This study simulated the average temperature and relative humidity (R. H.) conditions of Nairobi and Homabay districts of Kenya. Homabay district in Nyanza province is a leading producer of peanuts in Kenya (Ministry of Agriculture, 2004; Mutegi et al., 2012) while Nairobi is a major market outlet of peanuts sourced from within Kenya and other countries, and has both large and small scale peanut processing enterprises. Both Homabay and Nairobi have a high demand for raw peanuts and peanut products.

The temperature and R.H. were maintained at two levels $-19{ }^{\circ} \mathrm{C}$ and $64 \%$ R.H.; and $24{ }^{\circ} \mathrm{C}$ and $56 \%$ R.H. - being average conditions in Nairobi and Homabay districts of Kenya, respectively (Kenya Meteorological Department, 2010). The annual temperature and R.H. data during 2009 for Nairobi (Kenya Meteorological Department Headquarters) and Homabay (Kisumu Meteorological Station) were obtained from the Kenya Meteorological Department, which helped guide in the choice of temperature and R.H. for the storage experiment. Controls entailed storage of peanuts at ambient temperature $\left(22 \pm 3{ }^{\circ} \mathrm{C}\right)$ and R.H $(55 \pm 5 \%)$ at the Microbiology laboratory, Department of Food Science and Nutrition, University of Nairobi.

\subsection{Storage Bags and Peanut Varieties}

The storage containers used in the study were jute, polypropylene and polyethylene bags. Households and traders in Kenya commonly use polypropylene and polyethylene bags to store peanuts (Mutegi et al., 2013), while jute bags are recommended for storage (Kennedy \& Devereau, 1994). Visually clean peanut seeds of two local varieties (Homabay Local and Valencia Red) and two improved varieties (ICGV-SM 12991 and ICGV-SM 99568) were purchased from traders in western Kenya, the leading peanut producing region in the country. One and a half kilogram sample of each peanut variety was packed into each storage bag and replicated twice. The containers were incubated at three temperature and R.H. levels $\left(19{ }^{\circ} \mathrm{C}\right.$ and $64 \%$ R.H.; $24{ }^{\circ} \mathrm{C}$ and $56 \%$ R.H.; and ambient temperature $-22 \pm 3{ }^{\circ} \mathrm{C}$, and R.H. - $55 \pm 5 \%$ ). The experiment was run for a period of six months from April to September, 2011.

\subsection{Sampling}

Sampling entailed thoroughly mixing the $1.5 \mathrm{~kg}$ sample and drawing a $100 \mathrm{~g}$ sub-sample. The sub-sample was sub-divided into two equal portions of 50g where one portion was analyzed for rancidity (data not shown) and M.C., and the other for fungal infection and total aflatoxin level. Sampling was done for six months with an initial sampling before storage of the peanuts. The sub-samples taken for analysis were not returned to the storage containers.

\subsection{Determination of Moisture Content}

Moisture content of peanut kernels was determined using the oven drying method. The kernels were ground in a kitchen coffee grinder (Coffee Grinding Mill, Armco Kenya Ltd, Nairobi, Kenya). Two grams of the ground sample were placed on an aluminium dish, which was placed in a dry air oven (Memmert ULM 500, Büchenbach, Germany). The samples were dried at $105^{\circ} \mathrm{C}$ for 3 hours and the net weight of the dried sample determined. Each sample was replicated twice and the M.C. calculated as follows:

$$
\text { Moisture content (\% weight basis) }=\frac{\mathrm{M}_{0}-\mathrm{M}_{1}}{\mathrm{M}_{0}} \times 100
$$

Where: M0 - initial weight, in grams of test portion; M1 - final weight, in grams of dried test portion.

\subsection{Microbiological Assays}

Isolation of fungal species was carried out on Modified Dichloran Rose Bengal (MDRB) agar, using the protocol by Horn and Dorner (1998). From each of the $50 \mathrm{~g}$ ground sub-samples, 2 replicates of $2.5 \mathrm{~g}$ each were placed in calibrated centrifuge tubes, into which $10 \mathrm{~mL}$ of $2 \%$ water agar solution was added and mixed thoroughly. A 0.2 $\mathrm{mL}$ of the suspension was pipetted, spread onto MDRB plates, and incubated for 7 days at $30^{\circ} \mathrm{C}$, after which the colonies were identified and classified. Colony counts of $A$. flavus L-strain, A. flavus S-strain, A. parasiticus, A. tamari (Kita), A. niger (van Tieghem), Penicillium spp. and other fungal species were recorded.

Pure colonies on MDRB agar medium were sub-cultured onto the Czapek yeast extract agar (CYA; $1 \mathrm{~g} \mathrm{~K}_{2} \mathrm{HPO}_{4}$, $10 \mathrm{~mL}$ Czapek concentrate, $5 \mathrm{~g}$ powdered yeast extract, $30 \mathrm{~g}$ sucrose, $15 \mathrm{~g}$ agar), whose $\mathrm{pH}$ was adjusted to 7.2 and the plates incubated at $30{ }^{\circ} \mathrm{C}$ for 7 days. Species of Aspergillus section Flavi were identified based on colony colour, texture and conidial morphology characteristics (Klich, 2002), and by comparison with reference strains obtained from Dr. Bruce Horn (USDA National Peanut Research Laboratory, Dawson, Georgia, USA). 


\subsection{Screening Isolates of A. flavus and A. parasiticus for Aflatoxin Production}

A total of 250 isolates of $A$. flavus and A. parasiticus from the peanuts were screened for production of aflatoxin $\mathrm{B} 1, \mathrm{~B} 2, \mathrm{G} 1$ and G2. The screening was done in high sucrose yeast extract (YES) liquid medium (Horn \& Dorner, 1998). Conidia from single spore colonies of A. flavus (S- and L-strains) and A. parasiticus were inoculated into $6 \mathrm{~mL}$ vials containing $2 \mathrm{~mL}$ YES medium. Inoculated vials were incubated in the dark at $30{ }^{\circ} \mathrm{C}$ for 7 days, with intermittent shaking using a Stuart ${ }^{\circledR}$ vortex shaker (Bibby Scientific Limited, Staffordshire, UK). After incubation, $2 \mathrm{~mL}$ of chloroform was pipetted into each vial, the mixture vortexed for 60 seconds and left to stand overnight in a fume hood. Using a micro-pipette, $5 \mu \mathrm{L}$ of the chloroform extract was spotted on silica gel 60 thin layer chromatography (TLC) plates (EMD Chemicals Inc., Gibbstown, New Jersey, USA), along with analytical grade standards of aflatoxin B1, B2, G1 and G2 (ICRISAT, Patancheru, India). Previously selected toxigenic strains were used as positive controls. The plates were developed in chloroform, acetone and distilled water, in the ratio of $88: 12: 1.5$ respectively, until the solvent covered about $90 \%$ of the plate length. The plates were transferred to a darkroom and scored for the presence or absence of the four aflatoxin types under UV-light.

\subsection{Analysis of Peanut Samples for Aflatoxin Levels}

A $20 \mathrm{~g}$ sub-sample was drawn from the $50 \mathrm{~g}$ sample from each storage bag. The powder was triturated in a blender in $100 \mathrm{~mL}$ of $70 \%$ methanol $(70 \mathrm{~mL}$ absolute methanol in $30 \mathrm{~mL}$ distilled water, $\mathrm{v} / \mathrm{v})$ containing $0.5 \%$ potassium chloride $(\mathrm{w} / \mathrm{v})$ until thoroughly mixed. The extract was transferred to a conical flask and shaken for 30 min at $250 \mathrm{rpm}$. The extract was then filtered through Whatman No. 1 filter paper and diluted 1:10 in phosphate buffered saline containing $500 \mu \mathrm{L} / \mathrm{L}$ Tween-20 (PBS-Tween) and analyzed for aflatoxin contamination with an indirect Competitive Enzyme-Linked Immunosorbent Assay (ELISA) as described by Waliyar et al. (2005). This method has a detection limit of $0.5 \mu \mathrm{g} / \mathrm{kg}$.

\subsection{Data Analyses}

Data on fungal population and aflatoxin levels were subjected to analysis of variance (ANOVA) using PROC ANOVA procedure of Genstat Discovery 2 statistical software (Version 13, Lawes Agricultural Trust, Rothamsted Experimental Station, 2006) and means compared using Fisher's protected LSD test at 5\% significance level. For the fungal isolation data, infection frequency from each plate was pooled and mean frequency determined. Percentage data that were skewed were transformed using arcsine $\sqrt{ } \mathrm{p} / 100$ while other skewed data were transformed to $\log _{10}$ for data analysis and separation of means. Pearson correlation coefficient (SPSS version 16) was used to establish the correlations between different parameters.

For aflatoxin data, samples were grouped into three categories based on their aflatoxin content: samples with: $\leq 4$ $\mu \mathrm{g} / \mathrm{kg},>4 \mu \mathrm{g} / \mathrm{kg}$ to $\leq 10 \mu \mathrm{g} / \mathrm{kg}$, and $>10 \mu \mathrm{g} / \mathrm{kg}$. The $\leq 4 \mu \mathrm{g} / \mathrm{kg}$ category represents the European Union (EU) regulatory limit for total aflatoxin; peanuts in the second category would be rejected in the EU but would be accepted under the KEBS limits, while nuts in the third category would be rejected under the KEBS standards.

\section{Results}

\subsection{Moisture Content of Peanut Kernels}

There were significant $(\mathrm{p} \leq 0.05)$ differences in M.C. of peanut samples stored under different temperature and R.H. conditions and storage bags as presented in details in Mutegi et al. (In press). Moisture content of the samples varied from 3.3 to $6.9 \%$ and significantly $(\mathrm{p} \leq 0.05)$ decreased gradually from $5.6 \%$ before storage to $4.9 \%$ after four months of storage after which it stabilized. Overall ranking of M.C. in peanuts in different containers was as follows, in increasing levels: polypropylene (5.1\%), polyethylene (5.2\%) and jute bag (5.3\%). The mean M.C. of peanuts stored under different temperature and R.H. conditions was as follows: $24{ }^{\circ} \mathrm{C}$ and $56 \%$ R.H. (5.0\%), $22 \pm 3{ }^{\circ} \mathrm{C}$ and $55 \pm 5 \%$ R.H. (5.2\%), and $19^{\circ} \mathrm{C}$ and $64 \%$ R.H. (5.4\%). The M.C. of the four varieties varied significantly $(\mathrm{p} \leq 0.05)$ and was in increasing order: ICGV-SM $12991(5.1 \%)$, Homabay Local (5.2\%), ICGV-SM 99568 (5.2\%), and Valencia Red (5.3\%), respectively.

\subsection{Incidence of Fungal Species Associated With Peanuts}

Six fungal pathogens were commonly isolated from the peanut samples (Table 1). Incidence of the fungal species was significantly $(\mathrm{p} \leq 0.05)$ different and in decreasing order: Penicillium spp. (106.6 CFU/g), A. flavus L-strain (4.8 CFU/g), A. flavus S-strain (2.9 CFU/g), A. niger (2.6 CFU/g), A. parasiticus $(1.7 \mathrm{CFU} / \mathrm{g})$ and A. tamari $(0.2$ $\mathrm{CFU} / \mathrm{g}$ ). The population of Penicillium spp. was consistently high at the three temperature and R.H. regimes. Other frequently isolated moulds included Fusarium, Trichoderma and Eurotium spp. The peanut variety did not influence the diversity of fungal species isolated, but had a significant $(\mathrm{p} \leq 0.05$ effect on the total population of fungal pathogens with mean infection of the varieties ranked in the following decreasing order: Homabay Local (71.9 CFU/g), ICGV-SM 99568 (21.1 CFU/g), Valencia Red (17.2 CFU/g) and ICGV-SM 12991 (13.5 CFU/g). 
However, the type of storage bag as well as storage temperature and R.H. did not significantly ( $p \geq 0.05$ ) influence the total fungal population.

Population of the main aflatoxin producing fungi - A. flavus (S and L strains) and A. parasiticus - was influenced by the variety, storage bag, and temperature and R.H. (Table 2). However, there was no consistent pattern on how these conditions influenced the population of the moulds. Within each month, there was no significant $(\mathrm{p} \geq$ $0.05)$ variation in the population of the three fungal species except at the sixth month of storage. Overall, the population of $A$. flavus $\mathrm{L}$-strain was $66 \%$ higher than that of $A$. flavus $\mathrm{S}$-strain.

Peanut variety, storage temperature and R.H. significantly $(\mathrm{p} \leq 0.05)$ influenced the population of $A$. flavus (S and $\mathrm{L}$ strains) and $A$. parasiticus, whereas the type of storage bag did not have a significant $(\mathrm{p} \geq 0.05)$ effect (Figure 1). The highest and lowest population of the three pathogens was recorded when peanuts were stored at $19{ }^{\circ} \mathrm{C}$ and $64 \%$ R.H. (mean $=3.5 \mathrm{CFU} / \mathrm{g}$ ), and $24{ }^{\circ} \mathrm{C}$ and $56 \%$ R.H. (mean $=2.8 \mathrm{CFU} / \mathrm{g}$ ), respectively. Population of the three pathogens in different peanut varieties was ranked as follows: Homabay Local (5.6 CFU/g), ICGV-SM 12991 (2.8), ICGV-SM 99568 (2.1) and Valencia Red (1.9 CFU/g). 
Table 1. Mean colony forming units [CFU/g peanuts] of fungal species isolated from kernels of four peanut varieties stored in different bag types at different temperatures and relative humidity for six months

\begin{tabular}{|c|c|c|c|c|c|c|c|c|c|c|}
\hline Temp. $\left[{ }^{\circ} \mathrm{C}\right]$ & R.H. $^{\mathrm{a}}[\%]$ & Bag Type & Variety & $\mathrm{AF}[\mathrm{S}]$ & $\mathrm{AF}[\mathrm{L}]$ & AP & AN & AT & PEN & Others $^{\mathrm{d}}$ \\
\hline \multirow[t]{13}{*}{19} & \multirow[t]{13}{*}{64} & \multirow[t]{4}{*}{ Jute } & Homabay Local & 15.2 & 5.7 & 1.4 & 1.2 & 0.0 & 64.8 & 272.1 \\
\hline & & & Valencia Red & 0.2 & 5.5 & 2.4 & 1.7 & 0.0 & 10.2 & 59.8 \\
\hline & & & ICGV-SM 12991 & 0.0 & 8.3 & 0.0 & 0.2 & 0.0 & 5.5 & 84.3 \\
\hline & & & ICGV-SM 99568 & 3.1 & 10.7 & 0.0 & 0.7 & 0.0 & 36.0 & 36.0 \\
\hline & & \multirow[t]{4}{*}{ Polypro-pyrene } & Homabay Local & 8.6 & 5.2 & 2.4 & 1.4 & 0.0 & 640.5 & 212.6 \\
\hline & & & Valencia Red & 3.8 & 7.4 & 0.0 & 1.9 & 0.0 & 14.8 & 45.7 \\
\hline & & & ICGV-SM 12991 & 0.2 & 0.7 & 0.0 & 1.2 & 0.0 & 13.8 & 62.6 \\
\hline & & & ICGV-SM 99568 & 0.7 & 0.7 & 1.2 & 2.4 & 0.2 & 41.2 & 91.9 \\
\hline & & \multirow[t]{5}{*}{ Poly-ethylene } & Homabay Local & 1.7 & 14.8 & 0.5 & 0.7 & 0.0 & 79.8 & 169.5 \\
\hline & & & Valencia Red & 0.0 & 1.9 & 2.4 & 5.5 & 0.2 & 216.4 & 57.1 \\
\hline & & & ICGV-SM 12991 & 16.2 & 23.3 & 0.0 & 0.0 & 0.0 & 37.1 & 75.5 \\
\hline & & & ICGV-SM 99568 & 0.0 & 0.7 & 0.5 & 2.9 & 0.0 & 73.6 & 60.5 \\
\hline & & & Mean & 4.1 & 5.4 & 0.9 & 1.6 & 0.0 & 102.8 & 102.3 \\
\hline \multirow[t]{13}{*}{24} & \multirow[t]{13}{*}{56} & \multirow[t]{4}{*}{ Jute } & Homabay Local & 4.3 & 9.5 & 0.0 & 1.4 & 0.0 & 654.3 & 202.6 \\
\hline & & & Valencia Red & 5.0 & 12.6 & 0.0 & 6.2 & 2.4 & 44.3 & 54.8 \\
\hline & & & ICGV-SM 12991 & 0.0 & 2.9 & 0.0 & 0.2 & 0.0 & 28.6 & 49.0 \\
\hline & & & ICGV-SM 99568 & 0.0 & 0.2 & 0.0 & 1.0 & 0.0 & 191.4 & 43.3 \\
\hline & & \multirow[t]{4}{*}{ Polypro-pyrene } & Homabay Local & 2.1 & 4.5 & 0.0 & 1.0 & 0.0 & 240.2 & 97.9 \\
\hline & & & Valencia Red & 0.0 & 1.2 & 0.2 & 3.1 & 0.0 & 42.4 & 67.6 \\
\hline & & & ICGV-SM 12991 & 0.0 & 1.0 & 2.4 & 0.2 & 0.0 & 54.8 & 64.3 \\
\hline & & & ICGV-SM 99568 & 0.7 & 12.6 & 0.0 & 14.8 & 0.0 & 63.8 & 90.0 \\
\hline & & \multirow[t]{5}{*}{ Poly-ethylene } & Homabay Local & 7.1 & 9.8 & 4.8 & 12.4 & 0.0 & 234.0 & 102.0 \\
\hline & & & Valencia Red & 0.0 & 3.8 & 0.0 & 5.5 & 0.0 & 55.7 & 26.4 \\
\hline & & & ICGV-SM 12991 & 0.0 & 10.0 & 0.0 & 0.5 & 0.0 & 10.7 & 61.4 \\
\hline & & & ICGV-SM 99568 & 2.9 & 3.1 & 0.0 & 1.9 & 0.0 & 44.8 & 87.4 \\
\hline & & & Mean & 1.8 & 5.9 & 0.6 & 4.0 & 0.2 & 138.8 & 78.9 \\
\hline \multirow[t]{15}{*}{$\mathrm{RT}^{\mathrm{b}}$} & \multirow[t]{15}{*}{ AR.H. ${ }^{\mathrm{c}}$} & \multirow[t]{4}{*}{ Jute } & Homabay Local & 3.3 & 7.6 & 7.4 & 1.7 & 0.0 & 186.9 & 121.4 \\
\hline & & & Valencia Red & 0.2 & 0.7 & 0.0 & 2.1 & 0.0 & 37.4 & 35.0 \\
\hline & & & ICGV-SM 12991 & 0.2 & 7.1 & 0.0 & 1.0 & 0.0 & 28.6 & 61.7 \\
\hline & & & ICGV-SM 99568 & 2.4 & 2.6 & 0.0 & 1.4 & 0.2 & 19.0 & 130.7 \\
\hline & & \multirow[t]{4}{*}{ Polypro-pyrene } & Homabay Local & 16.0 & 4.0 & 2.4 & 3.6 & 0.0 & 150.5 & 124.3 \\
\hline & & & Valencia Red & 0.5 & 1.0 & 0.0 & 3.1 & 0.2 & 32.4 & 101.4 \\
\hline & & & ICGV-SM 12991 & 0.0 & 0.5 & 2.4 & 1.4 & 0.0 & 5.2 & 51.4 \\
\hline & & & ICGV-SM 99568 & 0.0 & 2.4 & 24.3 & 2.6 & 0.2 & 16.7 & 56.2 \\
\hline & & \multirow[t]{7}{*}{ Poly-ethylene } & Homabay Local & 3.6 & 7.9 & 2.4 & 0.7 & 2.4 & 386.9 & 162.1 \\
\hline & & & Valencia Red & 0.0 & 0.2 & 2.4 & 5.2 & 0.0 & 20.7 & 72.9 \\
\hline & & & ICGV-SM 12991 & 0.0 & 0.0 & 0.0 & 0.2 & 0.0 & 4.8 & 91.4 \\
\hline & & & ICGV-SM 99568 & 5.2 & 1.0 & 0.5 & 2.9 & 0.0 & 51.2 & 95.7 \\
\hline & & & Mean & 2.6 & 2.9 & 3.5 & 2.2 & 0.3 & 78.4 & 92.0 \\
\hline & & & Grand mean & 2.9 & 4.8 & 1.7 & 2.6 & 0.2 & 106.6 & 91.1 \\
\hline & & & Significance & $* * *$ & $* *$ & $* *$ & ** & ns & $* * *$ & $* * *$ \\
\hline
\end{tabular}

${ }^{a}$ - Relative humidity; ${ }^{b}$ - Room temperature $\left(22 \pm 3^{\circ} \mathrm{C}\right),{ }^{\mathrm{c}}$ - Ambient R.H. $(55 \pm 5 \%){ }^{\mathrm{d}}$ - Other fungal pathogens Fusarium spp., Trichoderma spp., Eurotium spp., unidentified fungal species.

$\mathrm{AF}[\mathrm{S}]$ - A. flavus S-strain, $\mathrm{AF}[\mathrm{L}]$ - A. flavus L-strain, AP - A. parasiticus, AA - A. alliaceaus, AC - A. caelatus, AN - A. niger, AT - A. tamarii, PEN - Penicillium spp.

$* *, * * *$ - Significant at $5 \%$ and $1 \%$ levels, respectively; ns - not significant $(\mathrm{p} \geq 0.05)$. 
Table 2. Colony forming units [CFU/g peanuts] of A. flavus [S and $\mathrm{L}$ strains) and A. parasiticus isolated from kernels of four peanut varieties stored in different bag types at different temperatures and relative humidity for six months

\begin{tabular}{|c|c|c|c|c|c|c|c|c|c|c|c|}
\hline \multirow[t]{2}{*}{ Temp. $\left[{ }^{\circ} \mathrm{C}\right]$} & \multirow[t]{2}{*}{ R.H. ${ }^{\mathrm{a}}[\%]$} & \multirow[t]{2}{*}{ Bag type } & \multirow[t]{2}{*}{ Variety } & \multicolumn{7}{|c|}{ Time [months] } & \multirow[t]{2}{*}{ Sig. } \\
\hline & & & & $0^{\mathrm{d}}$ & 1 & 2 & 3 & 4 & 5 & 6 & \\
\hline \multirow[t]{12}{*}{19} & \multirow[t]{12}{*}{64} & \multirow[t]{4}{*}{ Jute } & $\mathrm{HL}$ & 2.2 & 4.4 & 4.4 & 5.6 & 2.2 & 27.8 & 5.6 & ns \\
\hline & & & VR & 0.6 & 0.0 & 0.0 & 12.8 & 5.6 & 0.0 & 0.0 & $* *$ \\
\hline & & & 12991 & 0.0 & 0.0 & 0.0 & 0.0 & 19.4 & 0.0 & 0.0 & $* * *$ \\
\hline & & & 99568 & 7.2 & 0.0 & 0.0 & 12.2 & 12.8 & 0.0 & 0.0 & $* *$ \\
\hline & & \multirow[t]{4}{*}{ PP } & HL & 3.9 & 0.6 & 18.3 & 12.2 & 0.6 & 1.1 & 1.1 & $* *$ \\
\hline & & & VR & 7.2 & 0.0 & 0.0 & 7.2 & 6.1 & 0.0 & 5.6 & ns \\
\hline & & & 12991 & 0.0 & 1.1 & 0.0 & 1.1 & 0.0 & 0.0 & 0.0 & ns \\
\hline & & & 99568 & 2.2 & 0.0 & 0.6 & 1.1 & 2.2 & 0.0 & 0.0 & $* *$ \\
\hline & & \multirow[t]{4}{*}{ PE } & HL & 17.8 & 2.2 & 2.8 & 11.7 & 3.9 & 1.1 & 0.0 & ns \\
\hline & & & VR & 0.0 & 0.0 & 1.7 & 5.6 & 2.8 & 0.0 & 0.0 & ns \\
\hline & & & 12991 & 0.0 & 0.0 & 45.0 & 0.0 & 1.1 & 0.0 & 0.0 & $* * *$ \\
\hline & & & 99568 & 0.0 & 1.1 & 0.0 & 0.0 & 1.1 & 0.6 & 0.0 & ns \\
\hline \multirow[t]{12}{*}{24} & \multirow[t]{12}{*}{56} & \multirow[t]{4}{*}{ Jute } & HL & 3.9 & 1.7 & 0.6 & 11.7 & 6.7 & 1.7 & 6.1 & ns \\
\hline & & & VR & 0.0 & 0.0 & 0.0 & 1.7 & 0.0 & 39.4 & 0.0 & $* * *$ \\
\hline & & & 12991 & 0.6 & 0.0 & 0.0 & 0.6 & 5.6 & 0.0 & 0.0 & ns \\
\hline & & & 99568 & 0.6 & 0.0 & 0.0 & 0.0 & 0.0 & 0.0 & 0.0 & ns \\
\hline & & \multirow[t]{4}{*}{ PP } & HL & 1.1 & 7.8 & 1.1 & 1.7 & 1.1 & 2.8 & 0.0 & ns \\
\hline & & & VR & 2.2 & 0.0 & 0.6 & 0.0 & 0.6 & 0.0 & 0.0 & ns \\
\hline & & & 12991 & 0.0 & 0.0 & 1.1 & 1.1 & 5.6 & 0.0 & 0.0 & ns \\
\hline & & & 99568 & 1.1 & 0.0 & 5.6 & 0.6 & 22.8 & 0.6 & 0.6 & $* *$ \\
\hline & & \multirow[t]{4}{*}{ PE } & HL & 12.2 & 5.6 & 1.7 & 8.3 & 14.4 & 6.7 & 1.7 & ns \\
\hline & & & VR & 1.1 & 0.0 & 0.6 & 7.2 & 0.0 & 0.0 & 0.0 & $* *$ \\
\hline & & & 12991 & 0.0 & 0.0 & 0.0 & 23.3 & 0.0 & 0.0 & 0.0 & $* *$ \\
\hline & & & 99568 & 5.6 & 0.6 & 0.0 & 6.1 & 0.6 & 1.1 & 0.0 & ns \\
\hline \multirow[t]{14}{*}{$\mathrm{RT}^{\mathrm{b}}$} & \multirow[t]{14}{*}{ AR.H. ${ }^{c}$} & \multirow[t]{4}{*}{ Jute } & HL & 6.1 & 0.6 & 9.4 & 12.8 & 13.3 & 0.0 & 0.6 & $* *$ \\
\hline & & & VR & 0.0 & 0.0 & 0.6 & 1.1 & 0.0 & 0.6 & 0.0 & ns \\
\hline & & & 12991 & 0.0 & 0.0 & 5.6 & 11.1 & 0.6 & 0.0 & 0.0 & ns \\
\hline & & & 99568 & 0.0 & 0.0 & 5.6 & 6.1 & 0.0 & 0.0 & 0.0 & ns \\
\hline & & \multirow[t]{4}{*}{ PP } & HL & 1.1 & 1.1 & 7.2 & 6.7 & 8.3 & 5.6 & 22.2 & ns \\
\hline & & & VR & 0.6 & 0.6 & 0.0 & 2.2 & 0.0 & 0.0 & 0.0 & ns \\
\hline & & & 12991 & 0.6 & 0.0 & 0.0 & 0.6 & 0.0 & 5.6 & 0.0 & ns \\
\hline & & & 99568 & 0.6 & 0.0 & 55.6 & 5.6 & 0.6 & 0.0 & 0.0 & ns \\
\hline & & \multirow[t]{6}{*}{ PE } & HL & 15.0 & 1.1 & 0.6 & 1.1 & 6.1 & 0.0 & 8.3 & $* *$ \\
\hline & & & VR & 0.0 & 0.0 & 0.0 & 0.6 & 5.6 & 0.0 & 0.0 & ns \\
\hline & & & 12991 & 0.0 & 0.0 & 0.0 & 0.0 & 0.0 & 0.0 & 0.0 & ns \\
\hline & & & 99568 & 5.6 & 5.0 & 3.3 & 0.6 & 1.1 & 0.0 & 0.0 & ns \\
\hline & & & Mean & 2.7 & 1.2 & 5.0 & 5.0 & 4.2 & 2.6 & 1.4 & \\
\hline & & & Sig. & ns & ns & ns & ns & ns & ns & $* *$ & \\
\hline
\end{tabular}

a - Relative humidity; ${ }^{b}$ - Room temperature $\left(22 \pm 3{ }^{\circ} \mathrm{C}\right),{ }^{\mathrm{c}}$ - Ambient R.H. $(55 \pm 5 \%),{ }^{\mathrm{d}}$ - Before storage; PP Polypropyrene, PE - Polyethylene; HL - Homabay Local, VR -Valencia Red, 12991 - ICGV-SM 12991, 99568 -ICGV-SM 99568.

$* *, * * *$ - Significant at $5 \%$ and $1 \%$ levels, respectively; ns - not significant $(\mathrm{p} \geq 0.05)$. 

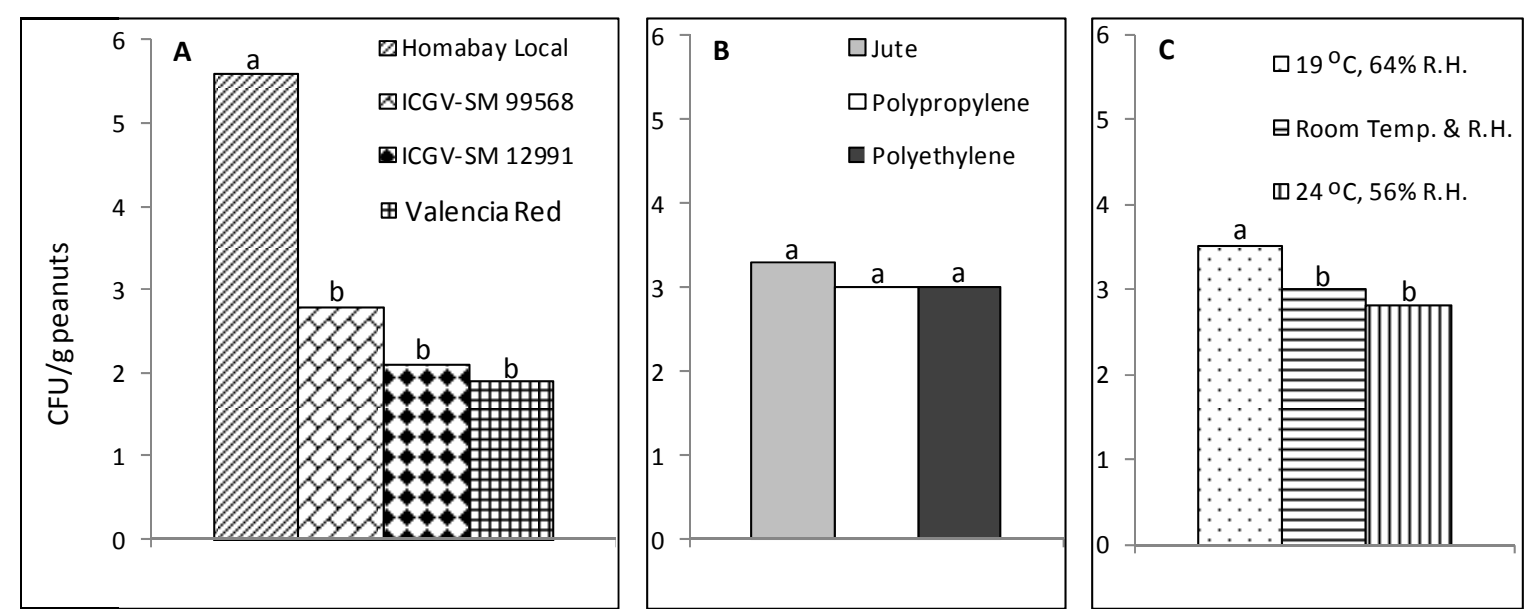

Figure 1. Mean colony forming units [CFU/g peanuts] of $A$. flavus [S and L strains) and A. parasiticus isolated from kernels of four peanut varieties (A), stored in different bag types (B), at different temperature and relative humidity levels $(\mathrm{C})$ for six months. Bar graphs for each parameter accompanied by the same letter are not significantly $(\mathrm{p} \geq 0.05)$ different

\subsection{Aflatoxin types Associated With A. flavus and A. parasiticus Isolates}

Out of the 255 isolates of $A$. flavus (S- and L- strains) and A. parasiticus assayed, 91\% were aflatoxigenic and produced at least one of the aflatoxin types, $\mathrm{B} 1, \mathrm{~B} 2, \mathrm{G} 1$ or G2. The most common aflatoxin type was AFG2, with a mean incidence of $89 \%$ (Table 3). Aflatoxin B2 $(60 \%)$ and AFB1 $(36 \%)$ were however detected in higher incidences compared to AFG1 (31\%). Isolates of A. flavus L- strain mainly produced AFB1 (39\%) while AFB2 (67\%) and AFG1 (42\%) were the main aflatoxin types produced by isolates of A. flavus S- strain and $A$. parasiticus, respectively.

Table 3. Percentage of A. flavus [S and L strains) and A. parasiticus isolates from peanuts producing different aflatoxin types

\begin{tabular}{|c|c|c|c|c|c|c|c|c|c|}
\hline \multirow[t]{2}{*}{ Aspergillus spp. } & \multicolumn{2}{|c|}{ AFB1 } & \multicolumn{2}{|c|}{ AFB2 } & \multicolumn{2}{|c|}{ AFG1 } & \multicolumn{2}{|c|}{ AFG2 } & \multirow{2}{*}{$\begin{array}{l}\text { Total } \\
{[\mathrm{n}]}\end{array}$} \\
\hline & $+\mathrm{ve}$ & -ve & $+\mathrm{ve}$ & -ve & $+\mathrm{ve}$ & -ve & $+\mathrm{ve}$ & $-\mathrm{ve}$ & \\
\hline A. flavus S-strain & 36.1 & 63.9 & 67.2 & 32.8 & 19.7 & 80.3 & 85.2 & 14.8 & 61 \\
\hline A. flavus L-strain & 38.5 & 61.5 & 63.7 & 36.3 & 30.8 & 69.2 & 90.1 & 9.9 & 182 \\
\hline A. parasiticus & 33.3 & 66.7 & 50.0 & 50.0 & 41.7 & 58.3 & 91.7 & 8.3 & 12 \\
\hline Mean & 36.0 & 64.0 & 60.3 & 39.7 & 30.7 & 69.3 & 89.0 & 11.0 & 255 \\
\hline
\end{tabular}

AFB1 - Aflatoxin B1, AFB2 - Aflatoxin B2, AFG1 - Aflatoxin G1, AFG2 - Aflatoxin G2.

$+v e,-v e$, positive and negative for the different aflatoxin types, respectively.

\subsection{Aflatoxin Levels in Peanut Samples}

There was a significant $(\mathrm{p} \leq 0.05)$ variation in the total aflatoxin levels - which ranged from $0-47.8 \mu \mathrm{g} / \mathrm{kg}$ among peanut kernels of the four varieties stored in different bag types (Table 4). Peanuts stored in polyethylene bags were $7.3 \%$ and $13.4 \%$ more contaminated than samples stored in polypropylene and jute bags, respectively. Overall, kernels of Homabay Local stored in polyethylene bags at $19{ }^{\circ} \mathrm{C}$ and $64 \%$ R.H. were the most contaminated (mean $=5.5 \mu \mathrm{g} / \mathrm{kg}$ ) while those of Valencia Red stored at room temperature and R.H. were the least contaminated (mean $=0.3 \mu \mathrm{g} / \mathrm{kg}$ ).

Under the different temperature-R.H-packaging material combinations, samples were assessed to determine the implications of such conditions on the safety of the nuts, based on existing regulatory thresholds. Overall, $89 \%$ of the peanut samples would have met the EU standards of a maximum of $4 \mu \mathrm{g} / \mathrm{kg}$ for total aflatoxin while $97 \%$ of the samples would have met the Kenyan regulatory threshold of $\leq 10 \mu \mathrm{g} / \mathrm{kg}$ (Table 4). 
Table 4. Mean proportion [\%] of aflatoxin contamination level categories $[\mu \mathrm{g} / \mathrm{kg}]$ for different peanut varieties stored at varying temperature and relative humidity conditions

\begin{tabular}{|c|c|c|c|c|c|c|c|c|}
\hline Temp. $\left[{ }^{\circ} \mathrm{C}\right]$ & R.H. ${ }^{\mathrm{a}}[\%]$ & Bag Type & Variety & $\leq 4$ & $>4-10$ & $>10$ & Range & Aflatoxin level $[\mu \mathrm{g} / \mathrm{kg}]^{\mathrm{d}}$ \\
\hline \multirow[t]{12}{*}{19} & \multirow[t]{12}{*}{64} & \multirow[t]{4}{*}{ Jute } & Homabay Local & 100.0 & 0.0 & 0.0 & $0-4.0$ & 1.5 \\
\hline & & & Valencia Red & 85.7 & 14.3 & 0.0 & $0-7.2$ & 2.0 \\
\hline & & & ICGV-SM12991 & 85.7 & 7.1 & 7.1 & $0-11.1$ & 2.0 \\
\hline & & & ICGV-SM 99568 & 85.7 & 14.3 & 0.0 & $0-5.7$ & 2.0 \\
\hline & & Polypro- & Homabay Local & 78.6 & 21.4 & 0.0 & $0-6.0$ & 2.1 \\
\hline & & \multirow[t]{3}{*}{ Pyrene } & Valencia Red & 85.7 & 7.1 & 7.1 & $0-37.9$ & 4.2 \\
\hline & & & ICGV-SM12991 & 92.9 & 7.1 & 0.0 & $0-4.6$ & 1.5 \\
\hline & & & ICGV-SM 99568 & 78.6 & 21.4 & 0.0 & $0-5.9$ & 1.9 \\
\hline & & Poly- & Homabay Local & 71.4 & 14.3 & 14.3 & $0-47.8$ & 5.5 \\
\hline & & \multirow[t]{3}{*}{ Ethylene } & Valencia Red & 85.7 & 14.3 & 0.0 & $0-5.9$ & 1.6 \\
\hline & & & ICGV-SM12991 & 92.9 & 7.1 & 0.0 & $0-4.2$ & 1.3 \\
\hline & & & ICGV-SM 99568 & 92.9 & 7.1 & 0.0 & $0-6.3$ & 1.5 \\
\hline \multirow[t]{12}{*}{24} & \multirow[t]{12}{*}{56} & \multirow[t]{4}{*}{ Jute } & Homabay Local & 92.9 & 7.1 & 0.0 & $0-4.6$ & 1.3 \\
\hline & & & Valencia Red & 85.7 & 7.1 & 7.1 & $0-11.4$ & 2.0 \\
\hline & & & ICGV-SM12991 & 92.9 & 7.1 & 0.0 & $0-4.4$ & 1.3 \\
\hline & & & ICGV-SM 99568 & 100.0 & 0.0 & 0.0 & $0-3.9$ & 1.0 \\
\hline & & Polypro- & Homabay Local & 78.6 & 14.3 & 7.1 & $0-12.0$ & 1.9 \\
\hline & & \multirow[t]{3}{*}{ Pyrene } & Valencia Red & 100.0 & 0.0 & 0.0 & $0-2.9$ & 1.0 \\
\hline & & & ICGV-SM12991 & 92.9 & 0.0 & 7.1 & $0-15.0$ & 1.7 \\
\hline & & & ICGV-SM 99568 & 92.9 & 7.1 & 0.0 & $0-7.9$ & 1.0 \\
\hline & & Poly- & Homabay Local & 85.7 & 14.3 & 0.0 & $0-7.0$ & 2.0 \\
\hline & & \multirow[t]{3}{*}{ Ethylene } & Valencia Red & 92.9 & 7.1 & 0.0 & $0-5.8$ & 1.4 \\
\hline & & & ICGV-SM12991 & 92.9 & 0.0 & 7.1 & $0-10.1$ & 1.4 \\
\hline & & & ICGV-SM 99568 & 92.9 & 7.1 & 0.0 & $0-4.6$ & 1.0 \\
\hline \multirow[t]{13}{*}{$\mathrm{RT}^{\mathrm{b}}$} & \multirow[t]{13}{*}{ AR.H. ${ }^{\mathrm{c}}$} & \multirow[t]{4}{*}{ Jute } & Homabay Local & 92.9 & 0.0 & 7.1 & $0-26.3$ & 2.9 \\
\hline & & & Valencia Red & 92.9 & 7.1 & 0.0 & $0-6.0$ & 1.6 \\
\hline & & & ICGV-SM12991 & 85.7 & 7.1 & 7.1 & $0-13.7$ & 1.8 \\
\hline & & & ICGV-SM 99568 & 100.0 & 0.0 & 0.0 & $0-4.0$ & 1.1 \\
\hline & & Polypro- & Homabay Local & 71.4 & 14.3 & 14.3 & $0-15.2$ & 3.3 \\
\hline & & \multirow[t]{3}{*}{ Pyrene } & Valencia Red & 100.0 & 0.0 & 0.0 & $0-1.8$ & 0.3 \\
\hline & & & ICGV-SM12991 & 85.7 & 14.3 & 0.0 & $0-8.9$ & 1.5 \\
\hline & & & ICGV-SM 99568 & 92.9 & 7.1 & 0.0 & $0-4.8$ & 1.0 \\
\hline & & Poly- & Homabay Local & 85.7 & 14.3 & 0.0 & $0-5.5$ & 1.9 \\
\hline & & \multirow[t]{4}{*}{ Ethylene } & Valencia Red & 92.9 & 7.1 & 0.0 & $0-4.5$ & 1.4 \\
\hline & & & ICGV-SM 12991 & 78.6 & 7.1 & 14.3 & $0-15.8$ & 2.8 \\
\hline & & & ICGV-SM 99568 & 85.7 & 14.3 & 0.0 & $0-5.3$ & 1.2 \\
\hline & & & Mean & 88.9 & 8.3 & 2.8 & $0-47.8$ & 1.8 \\
\hline
\end{tabular}

${ }^{a}$ - Relative humidity; ${ }^{\mathrm{b}}$ - Room temperature $\left(22 \pm 3^{\circ} \mathrm{C}\right),{ }^{\mathrm{c}}-$ Ambient R.H. $(55 \pm 5 \%),{ }^{\mathrm{d}}-$ Mean aflatoxin concentration. 


\subsection{Correlation Among Parameters Associated With Aflatoxin Contamination}

Different parameters were correlated to each other with different coefficients (Table 5). Moisture content was weakly correlated $(\mathrm{r}=-0.003)$ to the population of $A$. flavus ( $\mathrm{S}$ and $\mathrm{L}$ strains) and A. parasiticus. However, M.C. and total aflatoxin level were moderately positively correlated $(\mathrm{r}=0.046)$. Likewise, the total aflatoxin level was positively correlated $(\mathrm{r}=0.079)$ with the population of $A$. flavus ( $\mathrm{S}$ and L strains) and A. parasiticus.

Table 5. Correlation matrix of different parameters associated with aflatoxin contamination of peanuts

\begin{tabular}{llll}
\hline & Moisture content & Microbial population $^{\text {a }}$ & Aflatoxin level \\
\hline Moisture content & & \\
Microbial population $^{\mathrm{a}}$ & $-0.003 * *$ & & \\
Aflatoxin level & $0.046^{* *}$ & $0.079^{* *}$ & \\
CFU/g peanuts of A. flavus (S and L strains) and A. parasiticus. \\
*** - Significant at $5 \%$ and $1 \%$ levels, respectively.
\end{tabular}

\section{Discussion}

Six fungal pathogens - Penicilium spp., A. flavus L-strain, A. flavus S-strain, A. niger, A. parasiticus and A. tamari - were commonly isolated from the peanut samples. Previous studies have reported isolation of diverse fungal pathogens from peanuts in Kenya (Mutegi et al. 2012; Wagacha et al., 2013). Although A. flavus and A. parasiticus are the species most frequently implicated in aflatoxin contamination (Cotty, 2006), the wide fungal species diversity poses a health risk of exposing peanut consumers to other secondary metabolites. The high incidence of Penicillium spp. and A. niger is particularly of great health concern since both produce a wide spectrum of secondary metabolites. Among mycotoxins produced by Penicillium spp. are ochratoxins, patulin and citrinin (O'Brien et al., 2006), while A. niger produces, ochratoxin A and malformins among others (Frisvad, Smedsgaard, Samson, Larsen, \& Thrane, 2007; Weidenbörner, 2008). Although Fusarium spp. were isolated in low incidence, their infection of peanuts implies a health risk to consumers since they produce a wide range of mycotoxins such as fumonisins, trichothecenes, zearalenone and moniliformin among others (Weidenbörner, 2008).

Temperature $\left(32{ }^{\circ} \mathrm{C}\right.$ to $\left.33{ }^{\circ} \mathrm{C}\right)$, R.H. $(83 \%$ - $85 \%)$, water activity $(0.83$ to 0.97$)$, and M.C. $(>14 \%)$ are the most important factors influencing the growth of $A$. flavus in peanuts stored in enclosed facilities (Nakai et al., 2008) and aflatoxin contamination (Soler et al., 2010). Dry grains keep longer and safe from moulds because the water activity required for their growth is not met (Sanders, Shubert, \& Pattee, 1982). However, high humidity conditions in many tropical countries constrain efforts to dry peanuts to acceptable moisture levels (Mestres et al., 2004), thereby increasing the risk of fungal growth and aflatoxin contamination.

Significantly higher fungal population and M.C. of kernels stored in jute bags were recorded compared to peanuts stored in polypropylene and polyethylene bags. Similar to the findings in the current study, Bulaong and Dharmaputra (2002) reported that fungal population was significantly higher in peanuts stored in jute bag than in polypropylene bag and in jute bag lined with polyethylene. Although jute bags are recommended for storage of grains, they easily absorb moisture from the environment compared to polypropylene and polyethylene bags which are non-absorptive but tend to trap heat within (Kennedy \& Devereau, 1994).

Fungal pathogens isolated from peanuts have been reported to increase with increase in storage period (Bulaong \& Dharmaputra, 2002). Saleemullah, Khalil and Shah (2006) reported faster growth of Aspergillus spp. with increase in humidity and prolonged storage of peanuts for 12-18 months compared to short storage periods for 2-3 months. In the current study, the population of A. flavus and A. parasiticus gradually increased and peaked during the third month of storage followed by a general decline, which could be attributed to decline in M.C. of the kernels as well as fungal competition.

Homabay Local was the most susceptible variety to A. flavus and A. parasiticus while Valencia Red, another local variety was least infected. Attempts to develop aflatoxin resistant varieties have been carried out in various countries (Upadhyaya, Nigam, \& Thakur, 2004), but not in Kenya. These initiatives have led to the development of elite resistant varieties, which have been released as improved germplasm in Niger, Senegal and Burkina Faso (Upadhyaya, Nigam, \& Thakur, 2002). However, resistance in peanuts to aflatoxin contamination under all conditions has still not been achieved and breeding efforts continue (Guo et al., 2009). 
Although no consistent pattern was observed, the population of A. flavus (S and L strains) and A. parasiticus, and aflatoxin levels were influenced by the interaction of peanut variety, storage bag, and temperature and R.H. However, microbial population of the two species and aflatoxin contamination were weakly and moderately correlated to the M.C. of peanut kernels, respectively. Further studies are necessary to establish the effect of each of these parameters on the population of A. flavus and A. parasiticus and aflatoxin levels in peanuts.

The most important aflatoxin producers from a public health perspective are members of Aspergillus section Flavi and in particular A. flavus and A. parasiticus. There is phylogenetic evidence that Aspergillus flavus sensu lato may consist of several species (Chang, Ehrlich, \& Hua, 2006). Aspergillus flavus S-strain produces high levels of B-aflatoxins (Garber \& Cotty, 1997), with some S-strains producing both B- and G-aflatoxins (Barros et al., 2006; Cardwell \& Cotty, 2002). Aspergillus flavus L-strain typically produces less B-aflatoxins or no aflatoxins at all (Barros et al., 2006; Garber \& Cotty, 1997; Probst et al., 2011), while isolates of A. parasiticus can produce both B- and G-type aflatoxins (Ehrlich et al., 2004). Ability of A. flavus S-strain and A. parasiticus to produce both B- and G-type aflatoxins could possibly explain why AFG2 was detected in the highest incidence (89\%). However, A. flavus L- and S-strains were the main producers of AFB1 and AFB2, respectively while A. parasiticus mainly produced AFG2, which concurs with the findings by Garber and Cotty (1997). It is worth noting that $9 \%$ of the assayed isolates did not produce any of the four aflatoxin types. This is significant because application of atoxigenic A. flavus L-strains has successfully reduced aflatoxin contamination of peanuts and maize through competitive exclusion of aflatoxin producers mainly the $\mathrm{S}$ strains (Probst et al., 2011).

Overall, $89 \%$ of the peanut samples met the EU standards for total aflatoxin $(\leq 4 \mu \mathrm{g} / \mathrm{kg}$ ) while $97 \%$ of the samples met the Kenyan regulatory threshold of $\leq 10 \mu \mathrm{g} / \mathrm{kg}$. This implies that the storage conditions of the peanuts were fairly good. However, peanuts stored in polypropylene and polyethylene bags were $5.6 \%$ and $13.4 \%$ more contaminated with total aflatoxin than samples stored in jute bags, respectively. This could be attributed to retention of heat and moisture in polypropylene and polyethylene bags, which reduces peanuts quality, promotes fungal growth and aflatoxin contamination compared to jute bags.

\section{Conclusion}

Farmers and traders in Kenya should store their peanuts in jute bags as opposed to the commonly used polypropylene and polyethylene bags. Although jute bags easily absorb moisture, they are recommended because they allow good airflow compared to polypropylene and polyethylene bags which although non-absorptive trap heat within (Kennedy \& Devereau, 1994), thereby promoting deterioration of peanuts quality. Besides storage of peanuts at relatively low R.H., farmers and traders should ensure that the storage container does not promote critical increases in M.C. which would otherwise be conducive for increase in fungal population and aflatoxin contamination. Introduction of subsidies in the country to encourage packaging of peanuts and other grains in jute bags which are currently more expensive than the other two bag types should be explored as a viable option. Although $97 \%$ of the samples met the Kenyan regulatory threshold of $\leq 10 \mu \mathrm{g} / \mathrm{kg}$ for total aflatoxin, the risk of exposure of peanut consumers in Kenya to aflatoxin still exist due to the high population of aflatoxigenic fungi with $91 \%$ of $A$. flavus and $A$. parasiticus isolates testing positive for aflatoxin production.

\section{Acknowledgements}

The authors thank USAID, through the Peanut Collaborative Research Support Program (Peanut CRSP) funded by USAID cooperative agreement ECG-A-00-07-00001- for financial support in conducting this research, and ICRISAT for allowing us to use the aflatoxin research laboratory. Mr. Jeremiah M'thika and Ms. Rosemary Kamau of the Department of Food Science, Nutrition and Technology, University of Nairobi are gratefully acknowledged for technical support.

\section{References}

Barros, G. G., Torres, A. M., Rodriguez, M. I., \& Chulze, S. N. (2006). Genetic diversity within Aspergillus flavus strains isolated from peanut-cropped soils in Argentina. Soil Biology and Biochemistry, 38, 145-152. http://dx.doi.org/10.1016/j.soilbio.2005.04.028

Bulaong, S. S. P., \& Dharmaputra, O. S. (2002). Fungal population, aflatoxin and free fatty acid contents of peanuts packed in different bag types. Biotropia, 19, 1-25.

Cardwell, K., \& Cotty, P. J. (2002). Distribution of Aspergillus section Flavi among field soils from the four agroecological zones of the Republic of Benin, West Africa. Plant Disease, 86, 434-439. http://dx.doi.org/10.1094/PDIS.2002.86.4.434

CDC. (2004). Outbreak of aflatoxin poisoning-Eastern and Central provinces, Kenya, January-July, 2004. Retrieved July 25, 2013, from http://www.cdc.gov/mmwr/preview/mmwrhtml/mm5334a4.htm 
Chang, P.-K., Ehrlich, K. C., \& Hua, S. S. T. (2006). Cladal relatedness among Aspergillus oryzae isolates and Aspergillus flavus S and L morphotype isolates. International Journal of Food Microbiology, 108, 172-177. http://dx.doi.org/10.1016/j.ijfoodmicro.2005.11.008

Christensen, C. M., Mirocha, C. J., \& Meronuck, R. A. (1977). Molds, mycotoxins and mycotoxicoces. St. Paul, $\mathrm{MN}$ : American Association of Cereal Chemists.

Commission of the European Communities. (2006). Commission regulation (EC) No 1881/2006 of 19 December 2006 setting maximum levels for certain contaminants in foodstuffs. Official Journal of European Union L364, 5-24.

Cotty, P. J. (1994). Influence of field application of an atoxigenic strain of Aspergillus flavus on the populations of A. flavus infecting cotton bolls and on the aflatoxin content of cottonseed. Phytopathology, 84, 1270-1277. http://dx.doi.org/10.1094/Phyto-84-1270

Cotty, P. J. (2006). Biocompetitive exclusion of toxigenic fungi. In D. Barug, D. Bhatnagar, H. P. van Egmond, J. W. van der Kamp, W. A. van Osenbruggen, \& A. Visconti (Eds.), The Mycotoxin Factbook (p. 400). Wageningen, the Netherlands: Academic Publishers.

Ehrlich, K. C., Chang, P. K., Yu, J., \& Cotty, P. J. (2004). Aflatoxin biosynthesis cluster gene cypA is required for $\mathrm{G}$ aflatoxin formation. Applied and Environmental Microbiology, 70, 6518-6524. http://dx.doi.org/10.1128/AEM.70.11.6518-6524.2004

FAOSTAT. (2012). Retrieved June 12, 2013, from http://faostat.fao.org/site/339/default.aspx

Frisvad, J. C., Smedsgaard, J., Samson, R. A., Larsen, T. O., \& Thrane, U. (2007). Fumonisin B 2 production by Aspergillus niger. Journal of Agricultural and Food Chemistry, 55, 9727-9732. http://dx.doi.org/10.1080/02652030802366090

Garber, R. K., \& Cotty, P. J. (1997). Formation of sclerotia and aflatoxins in developing cotton bells infected by the $\mathrm{S}$ strain of Aspergillus flavus and potential for biocontrol with an atoxigenic strain. Phytopathology, 87, 940-945.

Guo, B., Yu, J., Holbrook Jr, C., Cleveland, T., Nierman, W. C., \& Scully, B. (2009). Strategies in prevention of pre-harvest aflatoxin contamination in peanuts: Aflatoxin biosynthesis, genetics and genomics. Peanut Science, 36, 11-20. http://dx.doi.org/10.3146/AT07-001.1

Hayma, J. (2003). The storage of tropical agricultural products. Wageningen, the Netherlands: STOAS Digigrafi.

Hell, K., \& Mutegi, C. (2011). Aflatoxin control and prevention strategies in key crops of Sub-Saharan Africa. African Journal of Microbiology Research, 5, 459-466. http://dx.doi.org/10.5897/AJMR10.009

Hell, K., Cardwell, K. F., Setamou, M., \& Poehling, H. (2000). The influence of storage practices on aflatoxin contamination in maize in four agroecological zones of Benin, West Africa. Journal of Stored Products Research, 36, 365-382. http://dx.doi.org/10.1016/S0022-474X(99)00056-9

Horn, B. W., \& Dorner, J. W. (1998). Soil populations of Aspergillus species from section Flavi along a transect through peanut-growing regions of the United States. Mycologia, 90, 767-776. http://dx.doi.org/10.2307/3761317

IARC. (1993). International agency for research on cancer monographs on the evaluation of carcinogenic risk to human. Lyon, France: IARC Press.

ICAR. (1987). Aflatoxin in groundnut - technologies for better crops. New Delhi, India: Indian Council of Agricultural Research.

Kennedy, L., \& Devereau, A. (1994). Observations on large-scale outdoor maize storage in jute and woven polypropylene sacks in Zimbabwe. In E. Highley, E. J. Wright, H. J. Banks, \& B. R. Champ (Eds.), Stored products protection. Proceedings of the sixth international working conference on stored-product protection, 17-23 April 1994, Canberra, Australia (pp. 290-295). Oxford, UK: CAB International.

Kenya Bureau of Standards. (2007). Kenya standard KS 694-1:2007. Shelled groundnut (Arachis hypogaea Linn.) - Specification. Part 1: Raw groundnut for table use. Nairobi, Kenya: Kenya Bureau of Standards Documentation Centre.

Kenya Meteorological Department. (2010). Climatological data, 2009. Nairobi, Kenya: Data Center, Kenya Meteorological Department. 
Klich, M. A. (2002). Identification of common Aspergillus species. Utrecht, the Netherlands: Centraalbureau voor Schimmelcultures.

Malaker, P. K., Mian, I. H., Bhuiyah, K. A, Akanda, A. M., \& Reza, M. M. A. (2008). Effect of storage containers and time on seed quality of wheat. Bangladesh Journal of Agricultural Research, 33, 469-477. http://dx.doi.org/10.3329/bjar.v33i3.1606

Mestres, C., Bassa, S., Fagbohoun, E., Nago, M., Hell, K., Vernier, P., ... Cardwell, K. F. (2004). Yam chip food sub-sector: hazardous practices and presence of aflatoxins in Benin. Journal of Stored Products Research, 40, 575-585. http://dx.doi.org/10.1016/j.jspr.2003.11.003

Ministry of Agriculture. (2004). Crop development division annual report. Nairobi, Kenya: Ministry of Agriculture, Kenya.

Mutegi, C. K., Ngugi, H. K., Hendriks, S. L., \& Jones, R. B. (2012). Factors associated with the incidence of Aspergillus section Flavi and aflatoxin contamination of peanuts in the Busia and Homabay districts of western Kenya. Plant Pathology, 61, 1143-1153. http://dx.doi.org/10.1111/j.1365-3059.2012.02597.x

Mutegi, C. K., Wagacha, J. M., Christie, M. E., Kimani, J. \& Karanja, L. (In press). Effect of storage conditions on quality and aflatoxin contamination of peanuts (Arachis hypogaea Linnaeus). International Journal of AgriScience

Mutegi, C. K., Wagacha, J. M., Kimani, J., Otieno, G., Wanyama, R., Hell, K., \& Christie, M. E. (2013). Incidence of aflatoxin in peanuts (Arachis hypogaea Linnaeus) from markets in Western, Nyanza and Nairobi Provinces of Kenya and related market traits. Journal of Stored Products Research, 52, 118-127. http://dx.doi.org/10.1016/j.jspr.2012.10.002

Nakai, V. K., Rocha, L. O., Goncalez, E., Fonseca, H., Ortega, E. M. M., \& Correa, B. (2008). Distribution of fungi and aflatoxins in a stored peanut variety. Food Chemistry, 106, 285-290. http://dx.doi.org/10.1016/j.foodchem.2007.05.087

Ngindu, A., Johnson, B., Kenya, P. R., Ngira, J. A., Ocheng, D. M., Nandwa, H., ... Siangok, T. A. (1982). Outbreak of acute hepatitis by aflatoxin poisoning in Kenya. Lancet, 319, 1346-1348. http://dx.doi.org/10.1016/S0140-6736(82)92411-4

O'Brien, M., Nielsen, K. F., O'Kiely, P., Forristal, P. D., Fuller, H. T. \& Frisvad, J. C. (2006). Mycotoxins and other secondary metabolites produced in vitro by Penicillium paneum Frisvad and Penicillium roqueforti Thom isolated from baled grass silage in Ireland. Journal of Agricultural and Food Chemistry, 54, 9268-9276. http://dx.doi.org/10.1021/jf0621018

Pildain, M. B., Frisvad, J. C., Vaamonde, G., Cabral, D., Varga, J., \& Samson, R. A. (2008). Two novel aflatoxin-producing Aspergillus species from Argentinean peanuts. International Journal of Systematic and Evolutionary Microbiology, 58, 725-735. http://dx.doi.org/10.1099/ijs.0.65123-0

Probst, C., Bandyopadhyay, R., Price, L. E., \& Cotty, P. J. (2011). Identification of atoxigenic Aspergillus flavus isolates to reduce aflatoxin contamination of maize in Kenya. Plant Disease 95, 212-218. http://dx.doi.org/10.1094/PDIS-06-10-0438

Saleemullah, I. A., Khalil, I. A., \& Shah, H. (2006). Aflatoxin contents of stored and artificially inoculated cereals and nuts. Food Chemistry, 98, 699-703. http://dx.doi.org/10.1016/j.foodchem.2005.06.034

Sanders, T. H., Shubert, A. M., \& Pattee, H. E. (1982). Maturity methodology and postharvest physiology. In H. E. Pattee, \& C. T. Young (Eds.), Peanut science and technology (pp. 625-627). Yoakum, TX: American Peanut Research and Education Society, Inc.

Shephard, G. S. (2008). Risk assessment of aflatoxins in food in Africa. Food Additives and Contaminants, 25 , 1246-1256. http://dx.doi.org/10.1080/02652030802036222

Soler, C. M. T., Hoogenboom, G., Olatinwo, R., Diarra, B., Waliyar, F., \& Traore, S. (2010). Peanut contamination by Aspergillus flavus and aflatoxin B1 in granaries of villages and markets of Mali, West Africa. Journal of Food, Agriculture and Environment, 8, 195-203.

Strosnider, H., Azziz-Baumgartner, E., Banziger, M., Bhat, R. V., Breiman, R., Brune, M., ... Wilson, D. (2006). Workgroup report: public health strategies for reducing aflatoxin exposure in developing countries. Environmental Health Perspectives, 114, 1989-1903. http://dx.doi.org/10.1289/ehp.9302

Suanthie, Y., Cousin, M. A., \& Woloshuk, C. P. (2009). Multiplex real-time PCR for detection and quantification of mycotoxigenic Aspergillus, Penicillium and Fusarium. Journal of Stored Products Research, 45, 139-145. 
http://dx.doi.org/10.1016/j.jspr.2008.12.001

Upadhyaya, H. D., Nigam, S. N., \& Thakur, R. P. (2002). Genetic enhancement for resistance to aflatoxin contamination in groundnut. In F. Waliyar, \& M. Adomou (Eds.), Summary proceedings of the seventh ICRISAT regional groundnut meeting for western and central Africa, 6 - 8 December 2000, Cotonou, Benin (pp. 29-36). Patancheru, India: ICRISAT.

Upadhyaya, H. D., Nigam, S. N., \& Waliyar, F. (2004). Aflatoxin contamination of groundnut: Conventional breeding for resistance. In J. Robens (Ed.), Proceedings of the third fungal genomics, fourth fumonisin, and sixteenth aflatoxin elimination workshops, 13 - 15 October 2003, Savannah, Georgia (p. 55). Beltsville, MD: USDA, ARS.

USAID. (2010). Staple foods value chain analysis. Retrieved July 25, 2013, from http://www.competeafrica.org/Files/Kenya_Staple_Foods_Value_Chain_Analysis_Study_JANUARY_2010. pdf

USDA. (2013). Corn update report. Retrieved June 10, 2013, from http://gain.fas.usda.gov/Recent\%20GAIN\%20Publications/Corn\%20Update\%20Report\%20_Nairobi_Keny a_1-14-2013.pdf

Wagacha J. M., Mutegi, C., Karanja, L., Kimani, J., \& Christie, M. E. (2013). Fungal species isolated from peanuts in major Kenyan markets: Emphasis on Aspergillus section Flavi. Crop Protection, 52, 1-9. http://dx.doi.org/10.1016/j.cropro.2013.05.004

Wagacha, J. M. \& Muthomi, J. W. (2008). Mycotoxin problem in Africa: Current status, implications to food safety and health and possible management strategies. International Journal of Food Microbiology, 124, 1-12. http://dx.doi.org/10.1016/j.ijfoodmicro.2008.01.008

Waliyar, F., Natre, B. R., Traore, A., Diarra, B., Kodio, O., \& Kumar, P. L. (2005). Pre- and postharvest management of aflatoxin contamination in groundnut. International Crops Research Institute for the Semi Arid Tropics: Institut d'Economie Rurale (IER), Mali. Retrieved June 12, 2013, from www.aflatoxin.info

Weidenbörner, M. (2008). Mycotoxins in foodstuffs. Berlin, Germany: Springer-Verlag.

Wu, F. (2010). The global burden of disease caused by foodborne aflatoxin. Retrieved from http://www.ifpri.org/sites/default/files/publications/aflacontrol_wp04.pdf

Wu, F., \& Khlangwiset, P. (2010). Health economic impacts and cost-effectiveness of aflatoxin reduction strategies in Africa: Case studies in biocontrol and postharvest interventions. Food Additives and Contaminants, 27, 496-509. http://dx.doi.org/10.1080/19440040903437865

\section{Copyrights}

Copyright for this article is retained by the author(s), with first publication rights granted to the journal.

This is an open-access article distributed under the terms and conditions of the Creative Commons Attribution license (http://creativecommons.org/licenses/by/3.0/). 